\title{
Trading Space Rivalry between Street Vendors and Shop-Based Traders in Bulawayo Metropolitan Province, Zimbabwe: A Conceptual Perspective for Co-Existence
}

\author{
Gwendoline Vusumuzi Nani \\ Graduate School of Business, Faculty of Commerce, \\ National University of Science and Technology, \\ Ascot, Bulawayo, Zimbabwe
}

DOI: https://doi.org/10.36941/ajis-2020-0071

\begin{abstract}
There has been a sharp increase in company closures in the Bulawayo Metropolitan Province, Zimbabwe, leaving people with no option but to turn to street vending to earn a living. The ever swelling number of street vendors on shop pavements and roadsides are subjecting formal shop owners to unfair competition as street vendors do not pay rentals and utility bills. That has caused rivalry for trading space between formal shop owners and street vendors. As a conceptual perspective, this study employed a non-empirical approach to evolve alternative ways of possible co-existence between street vendors and formal shop owners. The study concluded that street vending is a reality that cannot be ignored and, thus, recommended that co-existence of formal shop owners and street vendors should be harmonised so as to mitigate against the rivalry of trading space.
\end{abstract}

Keywords: conceptual perspective, harmonised co-existence, shop-based traders, street vendors, trading space rivalry

\section{Introduction}

Street vending has become a global phenomenon, especially in most developing countries (Kamunyori, 2007; Adhikari, 2011; Weng, 2013; Njaya, 2014; Anetor, 2015; Mramba, 2015), due to shrinking formal employment opportunities (Jimu, 2004). According to the Research and Advocacy Unit (2015), increase in street vending activity in Zimbabwe was a result of the implementation of Economic Structural Adjustment Programme (ESAP) in 1990s. The aftermath decline in the economy opened the informal sector as the major source of livelihood for arguably the vast number of Zimbabwean citizens; particularly as about 90 percent of Zimbabweans became unemployed (Chenga, 2013). The heightening unemployment rate manifested the gravity of the situation and, thus, accelerated the propensity for more people to join street vending as a source of income generation, especially as there are unlimited entry barriers.

Street vendors tend to undercut shop owners' prices in order to lure customers. As a result, cash strapped urban residents have no choice but to shun traditional supermarkets and buy from the street vendors (Munhazu, 2014). In some cases, formal shop owners try to make street vendors evicted from the pavements in front of their shops, but because the 'competitors' earn a living from street vending activities, they resist eviction (Mutsaka, 2015). The scenario creates rivalry between 
formal shop owners and street vendors who feel they have a right to occupy the spaces.

Street vendors do not only constitute a nuisance to formal shop owners but to other members of the public too. According to Butler (2015), at around 5pm, most pavements of Bulawayo streets in Zimbabwe are almost cordoned off by the activities of street vendors selling their wares. Trading activities of the street vendors result in congestion and make it almost impossible for pedestrians to navigate the streets as they manoeuvre to their homes after work. Street vendors pay no attention to the difficulties and worries by most pedestrians, who complain that the congestion makes them vulnerable to nefarious activities of pick pockets.

While street vendors feel that they have a right to trading space, the school of thought in this study is that public space ought to be a collective good to be enjoyed by all. To this extent, street vendors are perceived to be selfish, especially considering the appeal to rational reasoning that everyone should freely, comfortably and legitimately move about along the streets within the Bulawayo Metropolitan Province. It is an unfair situation where pedestrians have to weave in and out of street vendors' wares. Formal shop owners too, deserve cognisance respectful treatment. Were unlicensed and unrented street vendors to pay for vending, it is very unlikely that they would like the idea of others setting up 'shops' in front of their vending bays. Obviously, rivalry breeds between street vendors and formal shop owners. The rivalry is fuelled more by some other latent factors.

Despite intensified efforts by local government authorities and the police to curtail street vending activities, the number of street vendors continues to be on the increase. The situation thus calls for a more amicable resolution of the rivalry, possibly via mutual and harmonious co-existence strategies, especially as its intensity is inimical to general legitimate economic activities in the Metropolis.

\section{Research Objective}

The primary objective of this study was to unravel the factors that have contributed to the rivalry between formal shop owners and street vendors in the Bulawayo Metropolitan Province and to suggest ways of how the rivalry can be addressed and possibly resolved.

\section{Literature Review}

Bhowmik and Saha (2012:5) and Bromley (2000:1) define a street vendor as "a person who offers goods for sale to the public in places such as alleyways, avenues and boulevards". Molefe (2011), in his study on street vending in Botswana, explains street vending as "unregulated trading that takes place in public spaces such as on streets, sidewalks, bridges and pavements." Flodman-Becker (2004) contends that street vendors are part of a growing informal sector. However, engaging in academic debate on what the informal sector is or is not is beyond the scope of this article, but the following definition of the informal sector is meant to contextualise and situate the view in this article.

According to the International Labour Organisation (ILO) cited by Mhone (1996:1), the informal sector refers to:

"Very small-scale units producing and distributing goods and services, and consisting largely of independent, self-employed producers in urban areas of developing countries, some of who also employ family labour and/ or a few hired workers; which operate with very little capital, or none at all; which utilise a low level of technology and skills; which generally provide very low incomes and highly unstable employment to those who work in it. They are informal because they are unregulated and unrecorded in official statistics. They tend to have little or no access to organised markets and to formal credit institutions. They are often compelled by circumstances to operate outside the framework of the law."

In the context of this study, this definition is comprehensive as it describes the distinguishing characteristics of street vendors. Street vendors, by their very nature, fall into the category of the informal sector as they are mainly independent, self-employed, operate with very little capital, have 
no access to formal credit institutions and are not all recorded in official statistics. A formal trader is, therefore, one who is registered, pays tax to the government, pays trading-related utility bills and has access to facilities which an informal trader, in this context, a street vendor, does not have.

Adhikari (2011) explained that most countries of the world expected that street vending would stop to thrive and, thus go into extinction. The success of street vendors is attributed to the ability of selling products at relatively low prices compared to formal shops (Mensah, Yeboah-Manu, OwusuDarko \& Ablordey, 2010). The competitive advantage is achieved and sustained by not incurring rent expenses, paying taxes and other compulsory levies associated with formal businesses. As such, when they are asked to leave "their lands", angry street vendors usually refuse to budge, unless they are properly resettled, compensated, or rehabilitated (Weng, 2013).

Street vending is a very conspicuous experience in urban cities of most African countries such as Lagos, Aba, Bauchi, Port Harcourt, Abuja, Kaduna and Uyo all in Nigeria, as well as Accra and Kumasi in Ghana; just to mention a few (Basinski, 2009; Ekeanyanwu, 2012; Azaager \& Terwase, 2013; Frimpong, Abrokwah \& Owusu, 2013; Duru \& Nduka, 2014; Anetor, 2015; Ihesie \& Johnson, 2015; Bogoro, 2016). Common arguments adduced to justify street vending include that all fingers are not equal (Baskinski, 2009), poverty, lack of employable skills, minimal entry requirement (Azaager \& Terwase, 2013), means of making a living (Frimpong et al., 2013), overpopulation and high rates of unemployment (Duru \& Nduka, 2014). Specifically, “... street vendors are the most visible manifestation of the thriving informal economy in Lagos, Nigeria” (Baskinski, 2009: 3).

Studies on street vending have reported mixed findings, ranging from socio-economic relevance (Duru \& Nduka, 2014; Anetor, 2015; Ihesie \& Johnson, 2015), easy entry requirements, poverty, unemployment, material and socio-psychological deprivation (Azaager \& Terwase, 2013; Dube, 2013; Frimpong et al., 2013; Duru \& Nduka, 2014) to menace, traffic congestion (Frimpong et al., 2013). Others are negative effects on child education (Azaager \& Terwase, 2013; Duru \& Nduka, 2014), harassment as well as brutality in the hands of law enforcement agents (Baskinski, 2009; Ekeanyanwu, 2012), unfulfilled government promises coupled with non-affordability of market stores and extortions (Baskinski, 2009; Frimpong et al., 2013; Ihesie \& Johnson, 2015), hazards and threats to health (BCC, 2014) as in Tshili (2014) and breach of existing laws (Mhone, 1996).

Bulawayo, Zimbabwe's second largest city was hit by a wave of worker retrenchment as deindustrialisation took its toll (Bhebhe, 2012). An increasing number of people in Bulawayo, turned to vending in order to make ends meet as the economy continued to melt down with companies scaling down operations or shutting down (Dube, 2013). Most of the people, who lost their jobs together with those that were not employed at all, have literally flooded the streets to sell different wares that can generate some income in order to feed themselves and their families. The nuisance constituted by trading activities of some street vendors has compelled the Bulawayo City Council (BCC), on several occasions, to use local police to drive away illegal street vendors and confiscate their wares (Nkomo, 2015). The intention of the BCC has always been to ensure that wares are sold in safe and legal spaces by the vendors (Muvundisi, 2015). The use of local police to drive away street vendors has not yielded the intended results. Street vendors return to their places of business as soon as the law enforcement agents are out of sight (Chenga, 2013). Use of police or the army to chase away street vendors has also failed to achieve the intended results in other countries (Bromley, 2000; Hansen, 2004; Ndhlovu, 2010; Chenga, 2013; Weng, 2013). So, BCC has not been alone in failing to achieve the intended results. Alarming rates in the increase of street vending activities pose some hazards and threats to health, especially in terms of public sanitary facilities which do not match the increasing number of street vendors (BCC, 2014) as in Tshili (2014).

The increase in the number of street vendors has resulted in littering of the streets with garbage, other refuses and, thus, polluting the environment. Two way lanes have been turned into one way to accommodate vendors, thereby worsening the traffic congestion experienced in the Metropolis. Further, activities of the vendors have derailed a number of development plans of the local authority. The worsening situation is heightened by the seemingly acute shortage of manpower for BCC to effectively checkmate activities of the vendors. The resultant outcome has been the 
breaching of City by-laws by the street vendors.

An official of BCC explained that there were 4 ooo registered street vendors in 2013; but that the number had since grown to 6500 registered vendors in 2015. It is obvious that BCC finds it difficult to resist licensing new vendors as Bulawayo is generating sizeable income in fees charged for vending bays monthly (Tshili, 2014). Ndlovu (2015) notes that BCC allocates sites to registered vendors for daily fees of US\$1 to US\$3, depending on the location. The local police impose a fine of US\$5 on an illegal vendor, when arrested. More worrisome is that despite the reasonable amounts the vendors make on daily basis, many of them avoid paying legal fees and fines by simply playing hide and seek with local police, and other law enforcement agents (Basinski, 2009). Obviously, the number of street vendors must be more than what BCC sources officially report; as both legal and illegal street vendors continue to join each time a company closes down. Also, the increase has thus put a further strain on Council facilities as particularly the unlicensed vendors are benefitting from the services that they do not pay for. Bulawayo City Council (BCC) is not only faced with the challenge of handling unregistered street vendors; it also has to deal with licensed street vendors who have abandoned their vending bays, citing lack of viability as the bays are far away from customers. In this regard, Muvundusi (2015) explained that Bulawayo had more than 6 ooo unoccupied vending bays by August 2015, which had remained deserted because vendors complained of low customer patronage as most of the bays are located in secluded areas. So, once registered vendors leave their bays and sell elsewhere, they are deemed to be illegal where ever they will be operating from.

Considering it from yet the other side of the coin, it would be argued that by engaging in street vending, the people are creating jobs through self-reliance and empowering themselves. Jimu (2004) argues that being able to earn an income, no matter how little, is an empowering experience. Street vending does not only provide the vendors with income but also empowers them to value work and know how to work for what they want. Street vendors could be filling in a gap that formal shop owners are failing to fill. For example, in busy markets, trolley operators ferry merchandise that would have been bought from formal shops. However, this is not to condone some of the illegal activities or the discomfort that street vendors create for other stakeholders. Although most of what street vendors sell can be bought from the shops, they provide the goods at lower prices than shops do. One might argue that it is because they do not pay rentals and taxes that they are able to gainfully sell at lower prices. It could further be argued that they should be allowed to operate in order to fulfil customers' needs. Yet, it is reasonable to advance the argument that street vending should be restricted to designated sites.

In this regard, this study argues that street vendors should appreciate that they share space with others and, thus, need to operate from designated places. Therefore, change of mind sets to the possibility of mutual co-existence is the appropriate alternative. Though street vendors, in some way, are violating the rights of other stakeholders, unless the government creates job opportunities, the challenge of street vending will persist. More so, chasing street vendors away tends to leave one wondering how the people are expected to empower themselves in the face of the challenges facing the ailing Zimbabwean economy.

\section{Methodology}

This study is basically a non-empirical design, anchored on a conceptual perspective in an attempt to promote an alternative way of possible co-existence between street vendors and legally rented shopbased traders who operate within the Bulawayo Metropolitan Province in Zimbabwe. Insights were drawn from available literature in the study focus. However, literature on street vending and rented shop-based trading activities provided the bulk of the conceptual perspective on which the discussion was anchored. Thus, refereed journal articles and newspaper write-ups constituted the sources of information that served as the launch pad for the conceptual perspective anchorage to proffer alternative harmonised co-existence between the two groups of vendors in the Metropolis. The fact that the phenomenon of street vending activities has continued to be on the increase, thereby 
breeding the intensity of conspicuously escalating business space rivalry between street vendors and rented shop-based traders aroused the interest for the focus of the discussion in this study - a possible alternative strategy to engender co-existence and, thus, mitigate against trading space rivalry. This study is one of the very few studies that have explicitly explored the possibility of the coexistence of street vendors and formal shop owners with the hope of bringing some level of understanding in the sharing of trading space.

\section{Discussion}

\section{Street Vendors and Shop-based Traders Co-existence: Possible Alternative Strategies}

The following are among the challenges increasing street vending activities have posed in Bulawayo Metropolitan Province, and benefit to the BCC:

- Inadequate resources to house all street vendors (Tambo, 2015; Ruzvidzo, 2015). The situation is worsened by massive closure of companies.

- Unhealthy competition with street vendors who are now providing virtually every household commodity (Munhazu, 2014). The result is business space rivalry between street vendors and shop-based traders.

- Hindered movements. Pedestrians experience difficulties in manoeuvring through the streets when going home because street vendors are literally strewn all over the pavements (Tambo, 2015). The vendors appear to ignore the fact that Bulawayo City Council is not only meant to serve only the interests of street vendors.

- Street vendors are abandoning designated places, saying there are no customers (Tambo, 2015).

- There is ambience that BCC has to take care of but is failing to because of limited sanitary and garbage waste facilities (Ruzvidzo, 2015).

- There are tense and frustrating relationships with BCC officials, especially where traders' goods are constantly being impounded and confiscated (Tambo, 2015).

- BCC makes reasonable amount of money from the street vendors and, thus, the Council finds it difficult to resist the street vendors (Tshili, 2014).

BCC might want to forcefully send the vendors away from streets of the Metropolis. However, $\mathrm{BCC}$ just has to realise that street vending is a phenomenon that is likely to be with us for a long time, especially given the prevailing economic environment which is characterised by continued company closures. Moreover, as Tshili (2014) contends, shortage of manpower to evict the large number of street vendors exacerbates the challenge for BCC.

BCC can emulate the Zambian model in which, Ndhlovu (2011) contends that Zambian street vendors and formal shop owners co-exist. Street vendors buy their wares from formal shops and vend same on the streets. The direct transactions foster relationships in which formal and informal sectors co-exist to sustain a mutual system where trade and businesses thrive. Roever (2014) concurs that street trades have strong linkages with the formal economy. They source goods that they sell from formal businesses and many customers work in formal jobs. In some way, this guarantees a form of mutual co-existence. Njaya (2014:53) lends credence to this for Harare Metropolitan Province, where operations and socio-economic features of street food entrepreneurs are "equipped with life lines by street food vending sector which provides the urban economy with strong backward and forward economic linkages". In the context, Njaya (2014) further explains that workers from licensed shops and government offices constituted 30 per cent of street vendors' customers - a significant group of consumers of street foods. Essentially, Njaya's (2014) study of the Harare Metropolitan Province model extols some form of co-existence as street vendors are providing a service.

Street markets also establish business relations between production units, wholesale distribution centres and retail businesses at metropolitan, regional and transnational scales which are also some form of co-existence (Bartlett Development Planning Unit, 2015). Accordingly, Jimu (2003), 
explains that most street vendors sell farm produce or manufactured goods which have not been produced by them. Muiruri (2010) is of the view that for street vendors to improve their working conditions, they should be able to organise themselves. Databases of the vendors can then be compiled to be representatives of every identified sector.

Strengthening the existing Street Vendors Association in Bulawayo according to zones, and ensuring that meetings are held with zonal representatives, formal shop owners and representatives of the general public in the Bulawayo Metropolitan Province on a regular basis to discuss relevant issues would wield the potentials to engender the possibility of mutual co-existence between the vendors and shop-based traders and, ultimately, eliminate trading space rivalry between them. This is more so as the vendors, shop owners and the other public stakeholders, through the associations, would be able to defend their rights, secure access to the basic services, increase their bargaining power, and influence public policy. Respective association will ensure that their members comply with the agreed rules and regulations. Zonal association representatives can play an active role in ensuring that everyone is licensed and that the environment is kept clean and made to be user friendly for everyone. The different street vendor groups can be reporting to the Association, as umbrella body. When there are consultations with the Bulawayo City Council, a representative from each sector together with the umbrella body has to attend, and discuss to shape the way forward. What can be problematic is when BCC tries to mobilise or evict street vendors because they will disperse in all directions and BCC police cannot be everywhere. Bulawayo abides by environmental health standards.

Legalised street vendors can also assist in maintaining order because they would not want to see illegal street vendors take all their money home when they themselves pay rates and rentals. It can also be easy to organise regular training sessions on food and personal hygiene as well as nutrition. If these street vendors are left to mobilise themselves, they can do it because they understand one another better, and they can on their own take disciplinary actions against whoever among their members breaches the agreements. Street vendors are resisting perhaps because rules and regulations are imposed on them, and their voices are not heard. If their views are respected and their inputs are considered, they certainly will comply.

It is evident from the afore-mentioned that some form of co-existence between street vendors and formal shop owners is possible, even though it is not explicit. The urban environment thrives on an appropriate mix of formal and informal businesses. Therefore, it will be rewarding for authorities of metropolis to provide incentives for mutual co-existence between street vending shop-based trading business activities. If appropriately formalised and galvanized by governments at states or provinces and local levels, there will be mutual and peaceful co-existence between street vendors and shop owners. There are potential tendencies for governments to reap the benefits of increased revenue inflows through taxes and utility bills proceeds. However, the formalising modalities must ensure that they allay the fears of the street vendors who may be of the perception that governments are only interested in potential revenue, not welfare of the vendors.

Currently, BCC has dedicated some streets solely for weekend street vending. BCC can continue with that since there is orderliness in those designated places. In addition, BCC can also rent buildings where there is a lot of human traffic to house street vendors who continuously desert their vending bays because of low patronage by customers. The rate at which the number of street vendors is increasing indicates that BCC will likely end up with no spaces on the streets for use by others if $\mathrm{BCC}$ should consider the option of accommodating all vendors in the streets. However, authorities of the BCC must ensure that there are enough vending bays before they decide to evict street vendors. Some of the vendors might be willing to pay, but vending bays seem not to be adequately available. Instead of expending the available scarce financial resources on running battles with street vendors, it is advisable that $\mathrm{BCC}$ channels such funds on providing more vending bays. 


\section{Conclusions}

It appears as if the continued removal of street vendors from the streets is unsustainable due to resistance by street vendors and inadequate resources on the part of the local authority. Therefore, this study concludes that street vending is a phenomenon that is unlikely to go away. Thus, the study is of the opinion that evolving alternative strategies that can engender mutual co-existence between street vendors and shop-based traders would go a long way in alleviating the challenges the Bulawayo Metropolis faces from street vendors. However, a major caveat in this study is that for certain constraints such as the level of education of some of the street vendors and nature of trading endeavours; the street vendors, who are the major intended beneficiaries of the co-existence conceptually proposed by the study, are not likely to have access to and read the study. So, the onus of utilising the alternative proposed in the study lies mainly on the Bulawayo City Council (BCC) and other government authorities, and partly on the shop-based traders.

\section{Recommendations}

In this regard, the study recommends that the government and local authorities consider the alternative of making street vending a functionally integral part of the socio-economic life line of the Bulawayo Metropolis. The study emphasises the need for the authorities to take into cognisance and appreciate the positive contributions of the street vendors in various facets of the economy and, thus, come up with accommodating policies that would stimulate the potentials inherent in mutual coexistence of the trading groups for the benefits of the Bulawayo Metropolitan Province and its stakeholders. Certainly, commensurate dynamic bye-laws are essential legal tools or frameworks.

\section{References}

Adhikari, D. B. (2011). Income Generation in Informal Sector: A Case Study of the Street

Vendors of Kathmandu Metropolitan City. Economic Journal of Development Issues. Vol. 13 \& 14, (1-2). Combined Issue, 1-14.

Anetor, F. O. (2015). An Investigation into the Value of Street Vending in Nigeria: A Case of Lagos State. Journal of Marketing and Consumer Research, Vol. 11, 35-40.

Azaager, A. C. and Terwase, A. D. (2013). A Study of Street Children in Kaduna Metropolis. IOSR Journal of Humanities and Social Science, Vol. 15 (1), 44-49.

Bartlett Development Planning Unit. (2015). Street trading in the Global South: Practical

and Theoretical Challenges. One-day exchange seminar [Online] https://www.bartlett.ucl.ac.uk. [25 March 2015].

Basinski, S. (2009). All Fingers are Not Equal: A Report on Street Vendors in Lagos, Nigerian by Clean Foundation, Justice Sector Reform.

Bhebhe, N. (2012). Bulawayo's dying industry: Is there Hope for Revival? News Day. November. [Online] https://www.newsday.co.zw/bulawayo's-dying-industry-is-there- hope-for-revival. [o8 January 2016].

Bhowmik, S. K. and Siha, D. (2012). Street Vending in Ten Cities in India. Tata Institute of Social Sciences for National Association of Street Vendors of India. Delhi. June 2012.

Bogoro, A. G. (2016). Effects of Street Trading on Urban Areas in Nigeria. Global Advance Research Journal of Management and Business Studies, Vol. 5 (2), 051-056.

Bromley, R. (200o). Street Vending and Public Policy: A Global Review. International Journal of Sociology and Social Policy, Vol. 20 (1), 1-28.

Butler, T. (2015). Vending in Zimbabwe: New Reality or Passing Phase? [Online] www.sundaynews.co.zw/vendingin-zimbabwe-new-reality-or-passing-phase/. [20 November 2016.]

Chenga, N. (2013). Informal sector: The Major Challenge. Financial Gazette. [Online] www.financialgazette.co.zw. [07 January 2016].

Dictionary.cambridge.org/dictionary/english/co-exist.

Dube, M. (2013), Zimbabwe: BCC gives up on illegal vendors. [Online] www.thestandard.co.zw/2013/. [20 January 2016].

Duru, C. O. and Nduka, I. (2014). The Menace of Street Hawking in Aba Metropolis, South- East Nigeria. Journal of Medicine and Medical Sciences, Vol. 5 (6), 133-140. 
Ekeanyanwu, O. (2012). The Challenges of Abuja Street Traders. [Online] http://www.premiumtimesng.com/news/104869-the-challenges-of-abuja-street- traders.html. (21 July 2017).

Flodman-Becker, K. (2004). The Informal Economy. SIDA. [Online] www.rojasdatabank.info/sida.pdf. [05 February 2016].

Frimpong, S., Abrokwah, S. and Owusu, A. B. (2013). Analysis of the Spatial and Temporal Dynamics of Street Hawking: A Case Study of Accra Metropolitan Area. Journal of Geography and Geology, Vol. 5 (4), $169-198$.

Ihesie, C. A. and Johnson, O. E. (2015). Social Implications of and Factors Associated with Street Hawking among Children in Uyo, Akwa Ibom State, Nigeria. British Journal of Education, Society E Behavioural Science, Vol. 11(2), 1-9.Indigenisation Programme. [Online] https://www.icaz.org.zw. [o1 February 2016].

Jimu, I. M. (2004). An Exploration of Street Vendors' Contribution towards Botswana's vision of prosperity for all by 2016. Pula: Botswana Journal of African Studies. Vol. 18 (1).

Jimu, I. M. (2003). “Appropriation and Mediation of Urban Spaces: Growth, Dynamics and Politics of Street Vending in Blantyre, Malawi." Unpublished M.A. Dissertation (Development Studies), Department of Sociology, University of Botswana.

Kamunyori, S. W. (2007). A Growing Space for Dialogue: The Case of Street Vending in

Nairobi's Central Business District. Unpublished research project submitted to the Department of Urban Studies and Planning in Partial Fulfilment of the Requirements for the Degree of Master in City Planning at the Massachusetts Institute of Technology.

Mensah, P., Yeboah-Manu, D., Owusu-Darko, K. and Ablordey, A. (2002). Street Foods in Accra, Ghana: How Safe are they? Bulletin of the World Health Organisation, Vol. 8o (7), 546-554.

Mhone, G. C. Z. (1996). Conceptual and Analytical Issues in the Informal Sector in Southern Africa - An Analysis of Conceptual, Research and Policy Issues. Harare: Print Holdings.

Molefe, C. J. (2011). Beyond Modernist Planning: Understanding Urban Street Vending in Botswana. Paper presented at the International RC 21 Conference on The Struggle to Belong: Dealing with Diversity in $21^{\text {st }}$ Century Urban Settings, Governance and Diversity in Cities, Session 5, Amsterdam, 7-9 July 2011.

Mramba, N. R. (2015). The Conception of Street Vending Business (SVB) in Income Poverty Reduction in Tanzania. International Business Research. Vol. 8 (5), 120-129.

Muiruri, P. (2010). Women Street Vendors in Nairobi, Kenya. A Situational and Policy Analysis within a Human Rights Framework, Addis Ababa: OSSREA

Munhazu, T. (2014). Street Vendors Giving Shop Operators a Run for their Money. www.nehandaradio.com. [Online]. [11 February 2014].

Mutsaka, F. (2015) Court rules Zimbabwean Government cannot Use the Army to Drive

Sidewalk Vendors Away. Associated Press. [Online] www.blackpressusa.com/tag/zimbabwe. [o8 June 2015].

Muvundusi, J. (2015). Bulawayo Intensifies Street Vendors Crackdown. Daily News Live. [Online] https://dailynews.co.zw/articles/2015/12/03/byo-intensifies. [03 December 2015].

Ndhlovu, P. K. (2011). Street Vending in Zambia: A Case of Lusaka District. A research paper

submitted in partial fulfillment of the requirements of Master of Arts Degree in Development Studies, International Institute of Social Studies, The Hague, The Netherlands.

Ndlovu, N. (2015). Zimbabwe: Jobless Workers Turn to Street Vending but it's Tough.

[Online]www.barzawire.fm/en/farmer-stories. (o6 July 2015).

Ndlovu, R. (2015). Zimbabwe: Desperate to survive. Financial Mail. [Online] www.financialmail.co.za/.../2015/o6/11zimbabwe-desperate-to-survive. [03June 2015].

Njaya, T. (2014). Challenges of Negotiating Sectoral Governance of Street Vending Sector in Harare. Metropolitan, Zimbabwe. Asian Journal of Economic Modelling, 2014, Vol. 2 (2), 69-84.

Njaya, T. (2014). Nature, Operations and Socio-Economic Features of Street Food Entrepreneurs of Harare, Zimbabwe. IOSR Journal of Humanities and Social Science (IOSR-JHSS), Vol. 19 (4), 49-58.

Nkomo, N. (2015). Bulawayo City Escalates War against Street Vendors. [Online] www.wiego.org/news/. [19 August 2015].

Research and Advocacy Unit (2015). Vending in the Streets of Harare. [Online] www.researchandadvocacyunit.org/governance-programme-38. [o8 January 2016].

Roever, S. (2014). Street Vendors. Women in Informal Employment Globalising and Organising (WIEGO). [Online]www.academia.edu/. [13 January 2016].

Ruzvidzo, C. (2015). BCC allocates 700 vending bays. The Chronicle. [Online] www.chronicle.co.zw. [18 January 2016].

Tambo, B. (2015). Vending in Zimbabwe: new reality or passing phase? [Online] www.sundaynews.co.zw. (28 June 2015). 
Tshili, N. (2014). City Council in street vending poser. The Chronicle. [Online] http://www.chronicle.co.zw. [30 January 2014].

Weng, C. Y. (2013). Accommodate Street Vendors During the Urban Development Process: With Two Empirical Cases of Zhu Lian (ZL), and Guan Dong (GD) Public Markets in Hsinchu City Taiwan. Unpublished research project submitted to the Department of Urban Studies and Planning in Partial Fulfilment of the Requirements of the Degree of Master in City Planning at the Massachusetts Institute of Technology. 